\title{
EXPLORING THE BALANCE OF POWER IN THE OPERATOR/NON-OPERATOR RELATIONSHIP UNDER THE CAPL OPERATING PROCEDURE
}

\author{
Douglas G. Mills, Carolyn A. Wright, AND Julie J.M. INCH*
}

This article explores the differing rights and obligations of operators under the evolving versions of the Canadian Association of Petroleum Landmen (CAPL) Operating Procedure, particularly its 1981, 1990, and 2007 forms. It investigates the way in which the various iterations of the CAPL Procedure attempt to manage the balance between the competing interests of operators, and the way in which the courts have allocated responsibilities among the parties in their decisions. The evolution of the CAPL Procedure, in response to changes in industry or the courts' interpretation, speaks to the continued responsiveness of CAPL to industry needs.
Cet article examine les divers droits et diverses obligations des Exploitants en vertu des versions perpétuelles de la procédure opérationnelle de la Canadian Association of Petroleum Landmen (CAPL), tout particulièrement dans ses formulaires de 1981, 1990 et 2007. L'article porte sur les manières dont les diverses itérations de la procédure cherchent à gérer l'équilibre entre les intérêts conflictuels des Exploitants et la manière dont les tribunaux ont attribué les responsabilités parmi les parties dans leurs décisions. L'évolution de la décision de CAPL, après les changements dans l'industrie et l'interprétation de la cour, en dit long sur la réceptivité continue de CAPL à l'égard des besoins de l'industrie.

\section{TABLE OF CONTENTS}

I. INTRODUCTION . . . . . . . . . . . . . . . . . . . . . . . . . . . . . . . . . . . . . 364

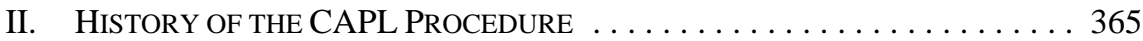

III. CURRENT INDUSTRY REALITY . . . . . . . . . . . . . . . . . . . . . . . . 365

IV. THE OPERATOR/NON-OPERATOR RELATIONSHIP AS

DEFINED UNDER THE CAPL PROCEDURE . . . . . . . . . . . . 366

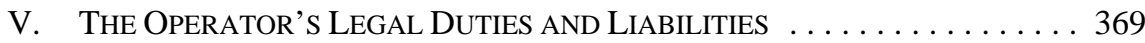

A. ARTICLE III AND ARTICLE VII OF THE CAPL PROCEDURE

— FUNCTIONS AND DUTIES OF THE OPERATOR . . . . . . . . 369

B. FIDUCIARY DUTIES $\ldots \ldots \ldots \ldots \ldots \ldots \ldots \ldots \ldots \ldots$

C. THE DUTY OF GOOD FAITH $\ldots \ldots \ldots \ldots \ldots \ldots \ldots \ldots \ldots$

VI. REPLACEMENT OF THE OPERATOR:

Alternative Non-Operator REMEdiEs . . . . . . . . . . . . . . 393

A. THE Operator Becomes BANKRUPT OR InSOLVENT $\ldots \ldots \ldots \ldots 393$

B. BY VOTE ........................... 393

C. BY DEFAULT OF THE OPERATOR WHICH

REMAINS UNRECTIFIED . . . . . . . . . . . . . . . . . . . . . . . . . 394

D. CHALLENGING THE OPERATOR . . . . . . . . . . . . . . . . . 394

VII. FinAL THOUGHTS: OPERATOR/NON-OPERATORS

AND THE EVOLVING CAPL PROCEDURE $\ldots \ldots \ldots \ldots \ldots \ldots \ldots$

Burnet, Duckworth \& Palmer LLP, Calgary, Alberta. The authors wish to acknowledge the contributions made to this article by Marika Strobl, Student-at-Law of Burnet, Duckworth \& Palmer LLP. 


\section{INTRODUCTION}

The Canadian Association of Petroleum Landmen (CAPL) Operating Procedure (the CAPL Procedure) is the standard industry document governing operations conducted on jointly held lands. The continued evolution of the operator's duties and liabilities, through the 1981-2007 versions of the CAPL Procedure, appears designed to increase the scope of the operator's protection in certain areas of the joint operations. In the words of Jim MacLean, one of the principal architects of these changes, "an Operator has much greater protection under [the 2007 Procedure ${ }^{1}$ ] than it does under prior versions of the document." 2 In a 2006 article, he explains that

\footnotetext{
[t]he net effect of those modifications [Clause 3.04 and 3.05 $\mathrm{A}^{3}$ ] and the expanded handling of Extraordinary Damages in Clause 4.04 is that an Operator has far better protection under this document [the 2007 Procedure] with respect to losses from the manner in which it planned or conducted field operations than under any of the prior versions of the document. This is particularly important because those are the operational obligations under which there is greatest likelihood for major loss.
}

[T] he modifications in the new draft are typically designed to provide Operators with protection they erroneously believe they already have. ${ }^{4}$

This article will explore these differing duties and obligations under the evolving versions of the CAPL Procedures and will seek to determine if this intended design holds true in practice.

The operator has a curious role - while it is a joint owner by virtue of its working interest, and has all of the rights and liabilities of an owner, it also has the duties and liabilities of an operator, with its status as an independent contractor. Although there is a legal distinction between the two roles, the line can sometimes become blurred and where an operator may have a choice between maximizing its own benefits (or limiting its obligations) to its own advantage, such choices will always be subject to the scrutiny of the non-operators. This, of course, leads to a careful consideration by all interested parties of the rights and obligations of the parties in any given circumstance. The authors investigate the way in which the various iterations of the CAPL Procedure attempt to manage the balance between these competing interests and the way in which the courts have allocated responsibilities among the parties in their decisions considering these evolving versions. 2007), online: CAPL <http://www.landman.ca/pdf/operating_procedures/2007/final/2007\%20 Operating\%20Procedure\%20Text\%20(Final\%20Annotated\%20Version\%202008).pdf> [2007 Procedure].

2 Jim MacLean, “2006 CAPL Operating Procedure — Liability and Indemnification Obligations” The Negotiator (December 2006) 4 at 5, online: CAPL <http://www.landman.ca/publications/Negotiator/ 2006/december/dec06_layout.pdf $>$.

3 Note that cl. 3.10A was also added to this list in the final version of the 2007 Procedure. MacLean, supra note 2 at 8-9. 


\section{History OF THE CAPL PRocedURE}

In the late 1960s, the rapidly developing oil and gas industry drove the need for certainty and predictability with the joint development of increasingly complex and expensive exploration and production activities in the Western Canadian Sedimentary Basin (WCSB). In response to this new reality, a standard form operating procedure was proposed by a group of Alberta landmen seeking to provide some predictability and consistency for operations conducted on joint lands. Although it was not immediately adopted as a standard form by industry, it proved to be the genesis of a very important development for joint operations in the oil and gas business in western Canada.

The scrutiny of the operating procedure continued and in 1971 a new version was introduced as the first official CAPL-sanctioned Procedure. The 1971 Procedure was reviewed and received with interest. However, ultimately many of the major producers continued to resist the use of a standard form agreement to attach to their farmout agreements and other forms of joint ventures. ${ }^{5}$

Finally in 1974, when PanAmerican Petroleum was about to commence a wide-scale farmout program in the WCSB, they requested a revised version of the 1971 Procedure to attach to their farmout agreements that would govern operations on the joint lands once earning had occurred. ${ }^{6}$ On the strength of this 1974 version of the CAPL Procedure, ${ }^{7}$ the standard form CAPL Procedure finally gained industry acceptance as the operating procedure of choice in Alberta, and generally for joint venture activities in the WCSB. Since that time, and in response to changing industry realities, economic influences, and judicial treatment of certain provisions of the various versions of the CAPL Procedures, CAPL has continued to review and amend the standard form agreement, producing revised versions known as the $1981,{ }^{8} 1990$, and, most recently, the 2007 Procedure. The focus throughout has been on the balance of rights and obligations between the joint venture parties to the CAPL Procedure, and the special role played by the operator in that context.

\section{CURRENT INDUSTRY REALITY}

Why has the CAPL Procedure had such wide acceptance in industry? As noted in the introduction to the 2007 Procedure:

[The CAPL Procedure] has fundamentally changed the way in which our industry has documented the business relationship between joint owners of P\&NG rights. Its success has also demonstrated the major

CAPL, 1971 CAPL Operating Procedure (Calgary: CAPL, 1971) [1971 Procedure]; CAPL, 1990 CAPL Operating Procedure (Calgary: CAPL, 1990) [1990 Procedure]. The 1971 Procedure is still encountered today, although it is not that common. One of the hallmarks of the 1971 CAPL Procedure is the 20-day right of first refusal (ROFR) response term, which strangely is more suited to the rapid pace of today's acquisitions and divestitures (A\&D) marketplace. The drafters of the 1990 Procedure, however, chose to include the 30-day ROFR as a way to prompt parties to consider more carefully their selection of a ROFR on disposition. 
business benefits of standardizing those aspects of our agreements for which our industry cannot afford to address basically the same business terms in a multitude of different ways. ${ }^{9}$

As joint venture parties establish the business deal to exploit a property, they do not have to expend unnecessary time and resources negotiating the terms of an operating procedure that will govern the relationship going forward. Use of the CAPL Procedure standard form is, for the most part, a highly predictable and efficient process for setting out the duties and liabilities of all of the joint operators, including the operator. Parties understand what their rights and obligations are, from one joint venture to the next, leading to efficiencies in accounting, operations, and land management. But as anyone involved in the oil and gas business also understands, the industry is known for its constant innovation, creativity, and risk-taking. This sometimes results in unintended consequences, or unanticipated situations, which bring the meaning and intention of the provisions of the CAPL Procedure into question. As the case law has demonstrated, the results are not always what the parties (or at least some of them) thought they had bargained for.

\section{THE OPERATOR/NON-OPERATOR RELATIONSHIP AS DEFINED UNDER THE CAPL PROCEDURE}

The CAPL Procedures used by parties in the oil and gas industry are intended, in most cases, to be the primary document defining the relationship and scope of obligations owed between operators and non-operators. However, generally speaking, unless the words of the governing contract expressly exclude liability for other causes of action, courts will look to the common law for alternative or concurrent remedies available to an aggrieved party.

This means that, while parties to a CAPL Procedure may believe they have restricted their obligations by the terms of the contract (thereby precluding liability for causes of action other than breach of that contract), this may not always be the case. Operators should be aware that their conduct in certain situations may give rise to additional duties and may result in liability outside the express terms of the relevant CAPL Procedures. ${ }^{10}$ Given this potential for additional liability outside of the terms of the contract, this article will also review the common law principles of negligence, fiduciary duties, and the duty of good faith in the context of the operator/non-operator relationship under the CAPL Procedures.

Under the CAPL Procedures, the operator maintains a separate status from the nonoperators; that is, the operator is an independent contractor. Clause 303 of the 1981 and 1990 Procedures are similar in their descriptions of the independent status of the operator. Clause 303 of the 1990 Procedure reads as follows:

The Operator is an independent contractor in its operations hereunder. The Operator shall supply or cause to be supplied all material, labor and services necessary for the exploration, development and operation of the joint lands and the operation of any production facilities for the joint account. The Operator shall determine the number of employees respecting its operations, their selection, their hours of labour and their operating_procedures/2007/final/Introduction\%20to\%20the\%202007\%20CAPL\%20Operating\%20 Procedure\%20(Final).pdf $>$. 
compensation. All employees and contractors used in its operations hereunder shall be the employees and contractors of the Operator. $^{11}$

Similar to the 1990 Procedure, cl. 3.03A of the 2007 Procedure describes the role of the operator as an independent contractor, but adds reference to the operator's responsibility for any liability and indemnification under art. 4.00. Clause 3.03 reads as follows:

The Operator is an independent contractor in activities hereunder. It will supply or cause to be supplied all material, labour and services reasonably necessary for Joint Operations. It will determine the number of employees and contractors required for Joint Operations, their selection, their hours of labour and their compensation, and they will be regarded as the Operator's employees and contractors. The Operator's status as an independent contractor does not alter its responsibility for liability and indemnification, which will continue to be governed by Article 4.00 and the other provisions of this Agreement. ${ }^{12}$

In the annotations to the 2007 Procedure, the Drafting Committee explains that they added reference to art. 4.00 "to minimize the possibility that the Operator could be responsible to the other Parties for ordinary negligence.”"13 However, as will be discussed in the subsequent section, the courts' interpretation of the 1981 Procedure has imposed liability on the operator for its ordinary negligence in certain situations, but as of Adeco Exploration Company Ltd. $v$. Hunt Oil Co. of Canada, ${ }^{14}$ the standard for the 1990 Procedure appears to be one of gross negligence for all joint operators. The 2007 Procedure has yet to be considered by the courts.

Under the 1981 Procedure and, similarly, the 1990 Procedure, cl. 1501 describes the relationship between the operator and non-operators as one of tenants in common:

\footnotetext{
The rights, duties, obligations and liabilities of the parties hereto shall be several and not joint or collective, it being the express purpose and intention of the parties that their interest in the joint lands ... shall be as tenants in common. Nothing herein shall be construed as creating a partnership, joint venture or association of any kind or as imposing upon any party ... any partnership duty, obligation or liability to any other party. $^{15}$
}

The relationship of the parties is described under cl. 1.05 of the 2007 Procedure as "No Partnership Or Fiduciary Relationship.” Similar to cl. 1501 in the 1981 and 1990 Procedures, the 2007 Procedure defines the operator/non-operator relationship as one of tenants in common. Clause 1501 in the 1981 and 1990 Procedures does not explicitly deny the existence of fiduciary obligations or in any way limit the scope of fiduciary obligations. However, in the 2007 Procedure the parties explicitly deny any fiduciary obligations, except for those prescribed in cl. 1.05A: (1) the commingling of funds; (2) the distribution of

CAPL, “2007 CAPL Operating Procedure, Annotations,” online: CAPL < http://www.landman.ca/pdf/ operating_procedures/2007/final/2007\%200perating\%20Procedure\%20Annotations\%20(Final 2008).pdf $>$.

142008 ABCA 214, 437 A.R. 33 [Adeco].

151981 Procedure, supra note 8. See also the 1990 Procedure, supra note 5. 
proceeds; and (3) maintaining the confidentiality of information. Clause 1.05A provides as follows:

Obligations Not Joint Or Collective — The Parties intend that their interests in the Joint Lands and in all other Joint Property will be held as tenants in common, subject to those modifications expressly provided under this Agreement. Nothing contained in this Agreement creates a partnership or association of any kind, imposes upon any Party any partnership duty, obligation or liability to any other Party.... Except as provided for: (i) the commingling of funds in Clause 5.07; (ii) the distribution of the proceeds of sale in Clause 6.06; and (iii) the obligation to maintain information confidential in Article 18.00, the Parties also confirm their intention that there is not any trust, trust duty or fiduciary relationship between them under this Agreement, provided that:

(a) the Parties recognize that this Subclause might not prevent such a trust, trust duty or fiduciary relationship being imposed at law or in equity; and

(b) the Parties do not intend this Subclause to lessen any duty of good faith (or similar duty) that may otherwise apply to them at law or in equity. ${ }^{16}$

Clause 1.05B is another modification to the 2007 Procedure that expressly recognizes that the joint operators are also competitors:

Parties Conduct Business As They See Fit — Each Party acknowledges that the Parties are engaged in the oil and gas business. Each Party is free to conduct its business in such manner as it, in its sole discretion, sees fit, even if it is (or may be) in competition with potential Joint Operations. Nothing in this Agreement restricts a Party from making elections or decisions in what it perceives to be its own interest, economic or otherwise, subject to: (i) any trust, trust duty or fiduciary relationship imposed at law or in equity; (ii) any duty of good faith (or similar duty) contemplated in Subclause 1.05A; and (iii) the other provisions of this Agreement, including any specific obligations not to exercise discretion unreasonably. ${ }^{17}$

Regardless of the parties' intention to define their relationship under contract, they may not succeed in excluding the courts' ability to find that a fiduciary relationship exists. The right of joint operators to compete may be subject to a court-imposed fiduciary relationship and subject to each party’s duty of good faith. ${ }^{18}$ In Bank of Nova Scotia v. Société Général (Canada) $^{19}$ the Alberta Court of Appeal held that the presence of cl. 1501 in the 1981 Procedure did not negate the possibility of a fiduciary relationship between the operator and non-operator. Justice Stratton stated:

[T] he presence of this section [Clause 1501] does not negative the existence of a fiduciary duty on the part of the Operator toward the Nonoperators. The section defines the relationship of all participants in the venture inter se; it does not override the fiduciary obligation imposed on the Operator when one considers the whole of the Agreement. ${ }^{20}$

Supra note 1 .

Ibid.

The test that the courts apply to determine the existence of a fiduciary relationship for a particular duty will be outlined below, followed by a discussion on the law of the duty of good faith. (1988), 87 A.R. 133 (C.A.) [Bank of Nova Scotia]. Ibid. at para. 12 . 
Clause 1.05C in the 2007 Procedure defines the parameters of the operator's obligations. Clause 1.05C is clear that the intention of the parties is that no special obligation exists for any party to apply knowledge that it obtains about lands other than the joint lands:

Operator's Obligations Limited To Agreement — Except as expressly provided in this Agreement, the Party appointed as Operator, will not, because of that appointment, have any additional obligation in contract, at law or in equity:

(a) to any other Party hereunder for lands other than the Joint Lands; or

(b) to apply knowledge or information it otherwise obtains about lands other than the Joint Lands in order to propose any Joint Operation or to take or refrain from taking any action hereunder. ${ }^{21}$

The 2007 Procedure does provide the courts with an element of certainty as to the parties' express intention on the applicability of fiduciary duties. The operator gives its express undertaking of loyalty to the non-operators for obligations associated with the commingling of funds, the distribution of proceeds, and to maintain confidential information (as set out in cl. 1.05A). The parties agree that all other obligations are not fiduciary obligations. As will be discussed in more detail below, this should reduce the risk of the court imposing an ad hoc fiduciary relationship, particularly in the context of a very recent Supreme Court of Canada decision - Galambos v. Perez ${ }^{22}$ — discussed in Part V.B.1, below.

\section{THE OPERATOR'S LEgAL DUTIES AND LiABILITIES}

\section{A. Article III And Article VII of the CAPL Procedure - FUNCTIONS AND DUTIES OF THE OPERATOR}

The CAPL Procedure has, in its progressive evolution, generally favoured the increased protection of the operator in certain areas. Historically, the oil and gas industry's perspective has been that operators should not be financially responsible to non-operators for the risk of conducting risky or significant operations unless the failure in such operation was caused by the gross negligence or wilful misconduct of the operator. The authors posit that while the 1981 Procedure may be seen to expose the operator to excessive liability, and the 1990 Procedure (as interpreted by Adeco, discussed below) perhaps protects the operator too much from liability, the 2007 Procedure appears designed to strike a balance between the two in an attempt to establish a more realistic balance of power and obligation between the operator and the non-operators. This article reviews the various changes in the 1981, 1990, and 2007 Procedures to consider these changes, and the courts' interpretation of them, in the context of these apparent goals. ${ }^{23}$ 


\section{The 1981 Procedure — ThE “ORdinARY NEGLIGENCE” STANDARD}

The operator's standard of care is set out in cl. 304 of the 1981 Procedure:

PROPER PRACTICES IN OPERATIONS - The Operator shall carry on all operations diligently, in a good and workmanlike manner, in accordance with good oilfield practices and in accordance with the Regulations. If any term or provision of this Operating Procedure is found to be inconsistent with or contrary to anything contained in the Regulations from time to time, the Regulations shall apply and this Operating Procedure shall be deemed modified to the extent necessary to comply with the Regulations and as so modified shall continue in full force and effect. ${ }^{24}$

The limits to operator liability are set out in cls. 401 and 402:

401 LIMIT OF LIABILITY - The Operator shall not be liable to the Joint-Operators for any loss or damage incurred by any of them relative to any operations carried out pursuant to this Operating Procedure except that:

(a) the Operator shall be solely responsible for and shall indemnify and save harmless each JointOperator from and against all actions, causes of action, suits, claims and demands by any person or persons whomsoever in respect of any loss, injury, damage or obligation to compensate to the extent of the risks against which the Operator is required to carry insurance as provided in Clause 311 and within the limits of such insurance, except that if an insurer is financially unable to pay all or any portion of a valid claim, the Operator shall be released from the indemnity and responsibility assumed by it under this Clause to the extent only of such inability to pay; and

(b) in addition to the provisions of Subclause (a) of this Clause, the Operator shall be solely liable for any loss or damage of whatsoever nature when such loss or damage is caused by the Operator's gross negligence or wilful misconduct but no act or omission of the Operator, its agents or employees, shall of itself be deemed gross negligence or wilful misconduct if it is done or omitted at the instruction of or with the concurrence of the Joint-Operators. If the Operator is liable under this Clause, the Operator shall indemnify and save harmless each Joint-Operator from and against all actions, causes of action, suits, claims and demands by any person or persons whomsoever in respect of any loss, injury, damage or obligation to compensate.

402 INDEMNIFICATION OF OPERATOR — Except as provided in Clause 401 all liabilities incurred by the Operator in the carrying out of any operations pursuant to this Operating Procedure, whether contractual or tortious, shall be for the joint account and shall be borne by the parties in accordance with their respective participating interests. $^{25}$

The interrelationship of cls. 304 and 401 was analyzed in Erehwon Exploration Ltd. v. Northstar Energy Corp. ${ }^{26}$ and affirmed several years later in Morrison Petroleums Ltd. v. Phoenix Canada Oil Co. ${ }^{27}$ It is clear that under the 1981 Procedure, the ordinary negligence standard is the standard of care owed by an operator to a non-operator; that is, the operator's 
obligation is to carry out operations in a good and workmanlike manner, in accordance with good oilfield practices. If the operator breaches this standard of care, it will be liable to the non-operators and, moreover, will not be indemnified by the non-operators. The non-operator is not obligated to prove the gross negligence of the operator in order to succeed under the 1981 Procedure. The 1981 Procedure thus places significant risk on an operator and departs significantly from the general understanding of industry participants that joint operators would share equally in all losses and gains that relate to the joint operations. ${ }^{28}$

\section{a. Erehwon Exploration Ltd. v. Northstar Energy Corp.}

Erehwon involved a dispute between the operator (Northstar Energy Corp.) and a nonoperator (Erehwon Exploration Ltd.) ${ }^{29}$ over certain fees charged by the operator to the joint operators on account of overhead charges. The non-operator alleged that the operator had levied inappropriate charges relating to accounting matters for joint operations.

In determining the appropriate standard of care to which an operator should be held accountable, the Court addressed the relationship between cl. 304 (which imposes on the operator a duty of "good oilfield practice") and cl. 401 (which limits the extent of operator liability to instances of gross negligence). Reconciling these two provisions, Hunt J. concluded that (1) the parties could not have intended the limitation in cl. 401 to override the obligation to act in accordance with good oilfield practice as set out in cl. 304, and (2) cl. 401 was arguably intended to deal with third party losses and not losses between the joint operators. $^{30}$

Rather than looking only at the specific language of the clause for interpretation, Hunt J. considered the document as a whole and found that the operator's position was untenable in light of the operator's covenants of performance contained elsewhere in the document. There was also an absence of specific language to support the operator's position: there was no clause providing that the non-operator's right of action against the operator was "strictly limited to action for loss, damage or costs caused by the gross negligence" 31 of the operator. Had this clause been included in the 1981 Procedure, it would have very clearly limited the operator's liability. Since the operator under cl. 304 was required to carry out joint operations in accordance with good oilfield practices, it was unlikely that "the parties could have intended Article IV to mean that the operator could then carry out its accounting obligations in a grossly negligent fashion.”32

\section{b. Morrison Petroleums Ltd. v. Phoenix Canada Oil Co.}

The issue of operator liability under the 1981 Procedure was revisited in Morrison. The non-operator (Morrison Petroleums Ltd.) claimed that the operator (Phoenix Canada Oil Co.) was negligent in the preparation of an authority for expenditure cost estimate, among other

See Craig Spurn, Jana Prete \& Melissa Zerebeski, “The 2007 CAPL Operating Procedure” (2009) 46 Alta. L. Rev. 427 at 450.

Though not particularly relevant, "Erehwon” is "nowhere," spelled backwards.

Erehwon, supra note 26 at para. 62.

United Canso Oil \& Gas Ltd. v. Washoe Northern Inc. (1991), 121 A.R. 1 at para. 320, cited in ibid. at para. 63.

Erehwon, ibid. at para. 65 
things. The operator argued that its liability was limited under cl. 401 of the 1981 Procedure to instances of its gross negligence or wilful misconduct. The Court disagreed.

The same reasoning applied in Erehwon was also applied in Morrison. Justice Moshansky confirmed Hunt J.'s holding in Erehwon that cls. 401 and 402 of the 1981 Procedure provide solely for indemnification of the non-operators by the operator for liability that the joint operators incur to third parties as a result of the gross negligence of the operator. ${ }^{33}$ Clauses 401 and 402 of the 1981 Procedure do not limit the operator's liability for direct losses to non-operators. Justice Moshansky further held that if the parties had intended to relieve the operator from liability for losses caused by the operator's own negligence (other than third parties' claims), they could have provided in the agreement that the joint operators would "not ... sue for anything except wilful or gross negligence.”34

\section{The 1990 Procedure - THE “Gross NeGLIGENCE/ WILFUL MISCONDUCT” STANDARD}

The operator's standard of care under the 1990 Procedure is set out in cl. 304: "PROPER PRACTICES IN OPERATIONS - The Operator shall conduct all joint operations diligently, in a good and workmanlike manner, in accordance with good oilfield practice and the Regulations.” ${ }^{35}$ Clauses 401 and 402 describe the limit of liability of the operator:

401 LIMIT OF LEGAL RESPONSIBILITY — Notwithstanding Clauses $303^{36}$ and 304, the Operator, its Affiliates, directors, officers, servants, consultants, agents and employees shall not be liable to the other Joint-Operators, or any of them, for any loss, expense, injury, death or damage, whether contractual or tortious, suffered or incurred by the Joint-Operators resulting from or in any way attributable to or arising out of any act or omission, whether negligent or otherwise, of the Operator or its Affiliates, directors, officers, servants consultants, agents, contractors or employees in conducting or carrying out joint operations, except:

(a) when and to the extent that such loss, expense, injury, death or damage relates to a risk against which the Operator is required to carry insurance....

(b) when and to the extent that such loss, expense, injury, death or damage is a direct result of, or is directly attributable to, the gross negligence or wilful misconduct of the Operator ....

To the extent that the conditions in Subclause (a) or (b) of this Clause apply (but subject to the exceptions provided therein), the Operator shall be solely liable for such loss, expense, injury, death or damage and, in addition, shall indemnify and save harmless each other Joint-Operator and its Affiliates, directors, officers, servants, consultants, agents and employees from and against the same and also from and against all actions, causes of action, suits, claims and demands by any person or persons whomsoever in respect of any such loss, expense, injury, death or damage, and any costs and expenses relating thereto. However, in no event shall the responsibility of the Operator prescribed by this Clause extend to losses suffered by the Joint-Operators

Morrison, supra note 27 at para. 90.

Ibid. at para. 92.

Supra note 5.

Clause 303 of the 1990 Procedure, ibid., reads: "INDEPENDENT STATUS OF OPERATOR — The Operator is an independent contractor in its operations hereunder... All employees and contractors used in its operations hereunder shall be the employees and contractors of the Operator." 
respecting the loss or delay of production from the joint lands, including, without restricting the generality of the foregoing, loss of profits or other consequential or indirect losses applicable to such loss or delay of production.

402 INDEMNIFICATION OF OPERATOR - Except as otherwise provided in Clause 401, the JointOperators hereby indemnify and save harmless the Operator, its Affiliates, directors, officers, servants, consultants, agents and employees from and against any and all actions, causes of action, suits, claims, demands, costs, losses and expenses resulting from loss, injury, death or damage respecting any person, which may be brought against or incurred or suffered by the Operator... in conducting joint operations. ${ }^{37}$

Clauses 304, 401, and 402 of the 1990 Procedure were not analyzed by the courts until 2008 in Adeco. In Adeco, the Alberta Court of Appeal held that:

(1) cl. 401 (the limit of legal responsibility clause) of the 1990 Procedure precluded the operator's liability for mere negligence, ${ }^{38}$ and

(2) cl. 401 applied to the operator's duty under cl. 304 (requiring operators to conduct joint operations in accordance with good oilfield practices). ${ }^{39}$

The Adeco lawsuit dealt with the operator's (Hunt Oil Company of Canada Inc.) failure to renew two Crown leases. The non-operators (Adeco Exploration Company Ltd. and Shaman Energy Corporation) sued the operator, alleging, among other things, that the operator had been negligent in allowing the leases to expire contrary to its obligations under cl. $309 .{ }^{40}$ The non-operators took the position that cl. 401 of the 1990 Procedure only limited the operator's liability with respect to third party claims and claims by non-operators arising from cls. 303 and 304 of the 1990 Procedure. Since the non-operators based their claim on cl. 309 (which deals with the maintenance of title documents), they argued that their claim was not subject to the gross negligence exclusion contained in cl. 401, but rather it was subject to the ordinary negligence standard. The operator took the position that the non-oerators had to prove gross negligence pursuant to $\mathrm{cl}$. 401 before the operator would be liable to the nonoperators.

The trial judge found that cl. 401 of the 1990 Procedure should be interpreted narrowly, so as not to exclude the operator's liability on an ordinary negligence standard:

Clauses like 401 [of the 1990 Procedure] should be narrowly interpreted, and in light of the clear obligation under Section 309 to maintain title documents, I am satisfied that they have breached their contractual obligation under Section 309 and are not exempted or saved under Section 401 . $^{41}$

Ibid. [emphasis added].

Adeco, supra note 14 at paras. 42-44.

Ibid. at para. 38 .

Clause 309 of the 1990 Procedure, supra note 5, reads:

MAINTENANCE OF TITLE DOCUMENTS - Except as otherwise provided herein or in the Agreement, the Operator shall, on behalf of the parties and for the joint account, comply with all the terms and conditions of the title documents including: (i) the payment of rentals; (ii) the payment of any encumbrances agreed to be borne for the joint account; and (iii) the performance of all things necessary to maintain the title documents in good standing and in full force and effect. 
The trial judge concluded that the operator was liable for the non-operators' damages as a result of the operator's ordinary negligence in failing to maintain title documents in accordance with its obligations under cl. 309.

The Court of Appeal disagreed with the trial court's narrow interpretation of cl. 401. The Court instead found that cl. 401 of the 1990 Procedure did operate to exclude the operator's liability for damages suffered by non-operators as a result of the operator's ordinary negligence. The exclusion of liability under cl. 401 applied to both the operator's duty to conduct all joint operations in accordance with good oilfield practice (under cl. 304), and the duty to maintain the title documents in good standing (under cl. 309).

In making its determination, the Court considered the language of $\mathrm{cl}$. 401. The Court found that the "language [of cl. 401] is clear and unambiguous.... [W] hat [the operator] failed to do in continuing the lease, constitutes an omission in conjunction with [the operator] carrying out the joint operation." 42 In reaching its conclusion, the Court reviewed the language of cl. 401 with respect to which actions (or inactions) attract the gross negligence standard. Clause 401 makes reference to "conducting or carrying out joint operations," which is defined in the 1990 Procedure as "an operation conducted hereunder for the joint account" ${ }^{43}$ and "for the joint account” is defined as "for the benefit, interest, ownership, risk, cost, expense and obligation of the parties in proportion to their respective working interests." ${ }^{44}$ The Court confirmed that, by the plain and ordinary meaning of the words in cl. 401, the test for determining the applicable standard of care is as follows: any activity of the operator that constitutes a joint operation for the joint account will attract the gross negligence standard - everything short of that standard is borne proportionately by all joint operators. ${ }^{45}$ The Court did not examine the question of the broader application of the limit of liability exclusion found in cl. 401 to activities of the operator that do not qualify as joint operations for the joint account. However, based on the Court's analysis, it is not certain that the application of the limit of liability exclusion set out in cl. 401 would extend beyond such a category. ${ }^{46}$

In applying the above test to the facts of the case in Adeco, the Court concluded that cl. 309 makes it clear that the operator's obligations with respect to the maintenance of title documents is on behalf of the parties and for the joint account, thus clearly attracting the gross negligence standard. ${ }^{47}$ Unfortunately for the operator, this was a pyrrhic victory — as the Court went on to find them guilty of gross negligence and therefore liable in any event.

The Court of Appeal's analysis on the standard to be applied probably went beyond that anticipated by the drafters of the 1990 Procedure. As a result of Adeco, it would appear that unless and until the courts are asked to consider the interplay between cl. 401 and another

Adeco, supra note 14 at para. 42.

Supra note 5, cl. 101(q).

Ibid., cl. 101(o).

Adeco, supra note 14 at paras. 42-43.

In a recent interview with Jim MacLean, he stated that the drafters of the 1990 Procedure were surprised by the Court of Appeal's broad application of the gross negligence standard. It was the intention of the drafters for the gross negligence standard to only apply to actual operations that leave the operator exposed to significant risk. All other "administrative" obligations, unless noted otherwise, were intended to be a simple contractual breach attracting the ordinary negligence standard.

Adeco, supra note 14 at para. 43. 
obligation of the operator under the 1990 Procedure, non-operators (under the 1990 Procedure) must establish gross negligence or wilful misconduct before being able to recover loss from the operator for any breach under the 1990 Procedure. Thus, at least arguably, the operator is afforded far greater protection from liability under the 1990 Procedure, as interpreted by the Court of Appeal in Adeco, than under any other version of the CAPL Procedure.

In considering Adeco, Scott Bower and Donald Greenfield predicted that the 2007 Procedure would be interpreted to the same effect as the 1990 Procedure; namely, that an operator is only responsible to the non-operators for omissions amounting to gross negligence or wilful misconduct. ${ }^{48}$ However, as the 2007 Procedure was ultimately drafted, we believe that the test for a non-operator will in fact be less onerous than that found in the 1990 Procedure. Specifically, we anticipate that under the 2007 Procedure, as adopted by industry, the operator will be required to indemnify the non-operators in circumstances where

(1) the operator is guilty of gross negligence (a standard that the operator will always be held to, under any of the CAPL Procedures);

(2) the operator is not guilty of gross negligence, but has breached a provision of the 2007 Procedure or was otherwise guilty of ordinary negligence (with the exception of the following provisions, which still require the gross negligence standard):

(a) a breach of good oilfield practice (cl. 3.04);

(b) a breach of the standards relating to health, safety, and the environment (cl. $3.05 \mathrm{~A}) ;^{49}$ or

(c) a breach related to the maintenance of title documents (cl. 3.10A); ${ }^{50}$ or

(3) the losses relate to something for which the operator was required to carry insurance.

Scott H.D. Bower \& Donald E. Greenfield, "Recent Judicial Developments of Interest to Oil and Gas Lawyers" (2010) 47 Alta. L. Rev. 607 at 629-31.

$49 \quad$ Clause 3.05 of the 2007 Procedure, supra note 1, reads:

Management of HSE Risks - Without limiting the obligations in Clause 3.04, the Operator will conduct each Joint Operation in compliance with the Regulations pertaining to HSE.... [T] Operator will, in planning and conducting Joint Operations:

(a) design and operate to standards that are intended to achieve sustained reliability and promote the effective management of HSE risks; and

(b) apply structured and documented HSE management systems and procedures consistent with those generally applied by a responsible operator under similar circumstances to manage HSE and security risks effectively and pursue sustained reliability of operations....

Notwithstanding the preceding portion of this Subclause, a breach of the obligations contained in this Clause 3.05 will not result in any form of liability (whether in tort, contract or otherwise) of the Operator to the Parties, except insofar as the conduct to which the breach pertains constitutes Gross Negligence or Wilful Misconduct for which the Operator is solely responsible under Article 4.00.

50 Clause 3.10A of the 2007 Procedure, ibid., reads:

Title Administrator Maintains - Except as otherwise provided in this Agreement, each Party is responsible for paying its share of lessor royalties under the Title Documents and its Working Interest share of any encumbrances borne for the Joint Account .... Notwithstanding the preceding portion of this Subclause, a breach of the obligations contained in this Subclause will not result in any form of liability (whether in tort, contract or otherwise) of the Operator or the Title Administrator to the Parties, except insofar as the conduct to which the breach pertains constitutes Gross Negligence or Wilful Misconduct for which it is solely responsible under Article 4.00. 
We believe that the provisions of the 2007 Procedure, described below, support this interpretation.

\title{
3. The 2007 PROCEDURE - A HYBRID OF THE \\ “ORdinARY NEGLiGENCE” STANDARD (1981 PROCEDURE) \\ AND THE “GROSS NEGLIGENCE/WILFUL MisCONDUCT” STANDARD \\ (1990 PROCEDURE)
}

Under the 2007 Procedure, only where there is a breach of cls. 3.04, 3.05A, or 3.10A (or in the case of an insured claim) are the non-operators required to prove gross negligence or wilful misconduct in order to be indemnified under cl. 4.00. The language of the 2007 Procedure is clear that, for all other breaches of the contract, the operator is held to the threshold of ordinary contractual liability and the ordinary negligence standard. Common to cls. 3.04, 3.05A, and 3.10A is the following "notwithstanding” language:

\begin{abstract}
Notwithstanding the preceding portion of this Clause, a breach of the obligations contained in this [Clause] will not result in any form of liability (whether in tort, contract or otherwise) of the Operator to the Parties, except insofar as the conduct to which the breach pertains constitutes Gross Negligence or Wilful Misconduct for which [the Operator] is solely responsible under Article $4.00 .^{51}$
\end{abstract}

No other clause in the 2007 Procedure attaches the above "notwithstanding” language.

Note, as well, that the term "Gross Negligence or Wilful Misconduct” has been defined for the first time in the 2007 Procedure. The definition is as follows:

\footnotetext{
“Gross Negligence or Wilful Misconduct” means any act, omission or failure to act (whether sole, joint or concurrent) by a person that was intended to cause, or was in reckless disregard of, or wanton indifference to, the harmful consequences to the safety or property of another person or to the environment which the person acting or failing to act knew (or should have known) would result from such act, omission or failure to act. However, Gross Negligence or Wilful Misconduct does not include any act, omission or failure to act insofar as it: (i) constituted mere ordinary negligence; or (ii) was done or omitted in accordance with the express instructions or approval of all Parties, insofar as the act, omission or failure to act otherwise constituting Gross Negligence or Wilful Misconduct was inherent in those instructions or that approval. ${ }^{52}$
}

MacLean explains that the above modifications were set out to clarify what was previously intended - all contractual breaches, other than those set out in cls. 3.04, 3.05A, and those items for which the operator is required to carry insurance, in respect of any version of the CAPL Procedure are intended to be held to a standard of ordinary contractual liability. ${ }^{53} \mathrm{He}$ states:

[T] he only thing that we've done in this area is to recognize that there is nothing in Article 4.00 that provides the Operator with an exemption from the normal legal rules that apply for breach of contract for all breaches

Ibid.

Ibid., cl. 101.

MacLean, supra note 2 at 7-8. 
of the contract other than Clause 3.04 and Subclause 3.05A.... ${ }^{54}$ For items like breaches of the Accounting Procedure, misappropriation of funds and loss of the Title Documents, we believe that the Operator is actually in no different position under the draft [2007 CAPL Procedure] than it is under any prior version of the Operating Procedure. ${ }^{55}$

Article 4.00 of the 2007 Procedure addresses the extent to which the operator will be held liable for losses and liabilities arising from the performance of operator duties under the Procedure:

\subsection{Indemnification of Operator}

This Clause applies except insofar as the Operator: (i) is solely responsible for any Losses and Liabilities under Clause 4.02; or (ii) may otherwise be liable to any Party for breach of any of its contractual obligations as Operator under this Agreement, other than for its duties under Clause 3.04, Subclause 3.05 or Subclause 3.10A. The Parties will indemnify and save harmless the Operator.... All such Losses and Liabilities for which that indemnification applies will be for the Joint Account, and will be borne by the Parties (including the Operator) in proportion to their respective Working Interests.

\subsection{Limit of Operator's Legal Responsibility}

The Operator, its Affiliates and their respective directors, officers and employees will not be liable to any of the Non-Operators for any Losses and Liabilities resulting from or in any way attributable to or arising out of any act, omission or failure to act, whether negligent or otherwise, of the Operator or its Affiliates and their respective directors, officers, agents, contractors or employees in the performance of the Operator's duties under this Agreement (including those in planning or conducting any Joint Operation), except insofar as:

(a) those Losses and Liabilities are a direct result of, or are directly attributable to the Gross Negligence or Wilful Misconduct of the Operator, its Affiliates or their respective directors, officers, employees, agents or contractors;

(b) the Operator may otherwise be liable to any Party for breach of any of its contractual obligations as Operator under this Agreement, other than for its duties under Clause 3.04, Subclause 3.05A or Subclause 3.10A; or

(c) those Losses and Liabilities relate to a risk against which the Operator is required to carry insurance for the Joint Account.

Insofar as Paragraph 4.02(a), (b) or (c) apply to impose obligations on the Operator for certain Losses and Liabilities, the Operator will, subject to Clause 4.04, be solely liable for them and, in addition, indemnify and save harmless each non-Operator and its Affiliates, directors, officers and employees from and against those Losses and Liabilities. However, all such Losses and Liabilities will initially be for the Joint Account until version of the 2007 Procedure requires that in addition to cls. 3.04 and 3.05A, a breach of cl. 3.10A also requires the non-operators to prove gross negligence or wilful misconduct. 
the Operator's responsibility therefor is finally determined, at which time it will promptly effect any required adjustment of accounts. ${ }^{56}$

Clause 4.04 restricts the types of damages that a party can seek from the court. It provides that no party is "responsible for any Extraordinary Damages ${ }^{57}$ suffered by any other Party," except where "the damaged Party is entitled to be indemnified ... by the Operator or another Party for any such damages suffered by third parties."58

\section{At a Glance — A COMPARATiVe ANALysis OF \\ OPERATOR DUTIES AND LIABILITIES UNDER THE 1981, 1990, AND 2007 PROCEDURE}

As has been noted above, the standard of care to which an operator will be held accountable for matters concerning joint operations will vary — some would argue widely - depending on the version of the CAPL Procedure in effect. The following chart sets out a comparison of the key duties of an operator under arts. III, V, and VII, and the standard of care relative to each duty under the 1981, 1990, and 2007 Procedures.

\section{KEY OPERATOR DUTIES AND THE CORRESPONDING STANDARD OF CARE OWED TO THE NON-OPERATORS}

\begin{tabular}{|c|c|c|c|c|}
\hline DUTY & $\begin{array}{l}\text { RELATED } \\
\text { CLAUSE }\end{array}$ & $\begin{array}{l}\text { BREACH OF DUTY } \\
\text { UNDER THE } 1981 \\
\text { PROCEDURE }\end{array}$ & $\begin{array}{l}\text { BREACH OF } \\
\text { DUTY UNDER THE } \\
1990 \text { PROCEDURE (AS } \\
\text { INTERPRETED BY } \\
\text { ADECO) }\end{array}$ & $\begin{array}{l}\text { BREACH OF } \\
\text { DUTY UNDER THE } \\
2007 \text { PROCEDURE }\end{array}$ \\
\hline $\begin{array}{l}\text { Control and } \\
\text { Management of } \\
\text { Operations }\end{array}$ & $\begin{array}{l}1981=\text { cl. } 301 \\
1990=\text { cl. } 301 \\
2007=\text { cl. } 3.01\end{array}$ & $\begin{array}{l}\text { Ordinary } \\
\text { contractual liability } \\
\text { Ordinary } \\
\text { negligence }\end{array}$ & $\begin{array}{l}\text { Gross negligence or } \\
\text { wilful misconduct }\end{array}$ & $\begin{array}{l}\text { Ordinary contractual } \\
\text { liability } \\
\text { Ordinary negligence }\end{array}$ \\
\hline $\begin{array}{l}\text { Proper } \\
\text { Practices in } \\
\text { Operations - } \\
\text { "Good Oilfield } \\
\text { Practice" }\end{array}$ & $\begin{array}{l}1981=\text { cl. } 304 \\
1990=\text { cl. } 304 \\
2007=\text { cl. } 3.04\end{array}$ & $\begin{array}{l}\text { Ordinary } \\
\text { contractual liability } \\
\text { Ordinary } \\
\text { negligence }\end{array}$ & $\begin{array}{l}\text { Gross negligence or } \\
\text { wilful misconduct }\end{array}$ & $\begin{array}{l}\text { Gross negligence or } \\
\text { wilful misconduct }\end{array}$ \\
\hline
\end{tabular}

$56 \quad$ Supra note 1 [emphasis added].

"Extraordinary Damages" are defined in cl. 1.01 of the 2007 Procedure, ibid. as meaning: except for any Losses and Liabilities respecting a Party's breach of the confidentiality obligations prescribed by Article 18.00, any Losses and Liabilities howsoever arising or occurring that: (i) are in the nature of consequential, indirect, punitive or exemplary damages (including compensation for business interruption, loss of profits, loss of opportunity, opportunity costs, reservoir or formation damage, the inability to produce Petroleum Substances or a delay in their production); or (ii) pertain to loss of well control during drilling or other well Operations, including, for this item (iii), associated Environmental Liabilities.

$58 \quad$ Ibid. For further discussion of the changes and additions to the 2007 Procedure, see Spurn, Prete \& Zerebeski, supra note 28 at 441-52. 


\begin{tabular}{|c|c|c|c|c|}
\hline DUTY & $\begin{array}{l}\text { RELATED } \\
\text { Clause }\end{array}$ & $\begin{array}{l}\text { BREACH OF DUTY } \\
\text { UNDER THE } 1981 \\
\text { PROCEDURE }\end{array}$ & $\begin{array}{l}\text { BREACH OF } \\
\text { DUTY UNDER THE } \\
1990 \text { PROCEDURE (AS } \\
\text { INTERPRETED BY } \\
\text { ADECO) }\end{array}$ & $\begin{array}{l}\text { BREACH OF } \\
\text { DUTY UNDER THE } \\
2007 \text { PROCEDURE }\end{array}$ \\
\hline $\begin{array}{l}\text { Books, } \\
\text { Records, and } \\
\text { Accounts }\end{array}$ & $\begin{array}{l}1981=\text { cl. } 305 \\
1990=\text { cl. } 305 \\
2007=\text { cl. } 3.07\end{array}$ & $\begin{array}{l}\text { Ordinary } \\
\text { contractual liability } \\
\text { Ordinary } \\
\text { negligence }\end{array}$ & $\begin{array}{l}\text { Gross negligence or } \\
\text { wilful misconduct }\end{array}$ & $\begin{array}{l}\text { Ordinary contractual } \\
\text { liability } \\
\text { Ordinary negligence }\end{array}$ \\
\hline $\begin{array}{l}\text { Health, Safety, } \\
\text { and the } \\
\text { Environment }\end{array}$ & $\begin{array}{l}1981=\text { N/A } \\
1990=\text { N/A } \\
2007=\text { cl. 3.05A }\end{array}$ & N/A & N/A & $\begin{array}{l}\text { Gross negligence or } \\
\text { wilful misconduct }\end{array}$ \\
\hline $\begin{array}{l}\text { Protection } \\
\text { from Liens }\end{array}$ & $\begin{array}{l}1981=\text { cl. } 306 \\
1990=\text { cl. } 306 \\
2007=\text { cl. } 3.06\end{array}$ & $\begin{array}{l}\text { Ordinary } \\
\text { contractual liability } \\
\text { Ordinary } \\
\text { negligence }\end{array}$ & $\begin{array}{l}\text { Gross negligence or } \\
\text { wilful misconduct }\end{array}$ & $\begin{array}{l}\text { Ordinary contractual } \\
\text { liability }\end{array}$ \\
\hline $\begin{array}{l}\text { Joint } \\
\text { Operator’s } \\
\text { Rights of } \\
\text { Access }\end{array}$ & $\begin{array}{l}1981=\text { cl. } 307 \\
1990=\text { cl. } 307 \\
2007=\text { cl. } 3.08\end{array}$ & $\begin{array}{l}\text { Ordinary } \\
\text { contractual liability } \\
\text { Ordinary } \\
\text { negligence }\end{array}$ & $\begin{array}{l}\text { Gross negligence or } \\
\text { wilful misconduct }\end{array}$ & $\begin{array}{l}\text { Ordinary contractual } \\
\text { liability }\end{array}$ \\
\hline $\begin{array}{l}\text { Surface Rights } \\
\text { and Regulatory } \\
\text { Licences }\end{array}$ & $\begin{array}{l}1981=\text { cl. } 308 \\
1990=\text { cl. } 308 \\
2007=\text { cl. } 3.09\end{array}$ & $\begin{array}{l}\text { Ordinary } \\
\text { contractual liability } \\
\text { Ordinary } \\
\text { negligence }\end{array}$ & $\begin{array}{l}\text { Gross negligence or } \\
\text { wilful misconduct }\end{array}$ & $\begin{array}{l}\text { Ordinary contractual } \\
\text { liability } \\
\text { Ordinary negligence }\end{array}$ \\
\hline $\begin{array}{l}\text { Maintenance of } \\
\text { Title } \\
\text { Documents }\end{array}$ & $\begin{array}{l}1981=\text { cl. } 309 \\
1990=\text { cl. } 309 \\
2007=\text { cl. } 3.10 \mathrm{~A}\end{array}$ & $\begin{array}{l}\text { Ordinary } \\
\text { contractual liability } \\
\text { Ordinary } \\
\text { negligence }\end{array}$ & $\begin{array}{l}\text { Gross negligence or } \\
\text { wilful misconduct }\end{array}$ & $\begin{array}{l}\text { Gross negligence or } \\
\text { wilful misconduct }\end{array}$ \\
\hline $\begin{array}{l}\text { Production } \\
\text { Statements and } \\
\text { Reports }\end{array}$ & $\begin{array}{l}1981=\text { cl. } 310 \\
1990=\text { cl. } 310 \\
2007=\text { cl. } 3.12\end{array}$ & $\begin{array}{l}\text { Ordinary } \\
\text { contractual liability } \\
\text { Ordinary } \\
\text { negligence }\end{array}$ & $\begin{array}{l}\text { Gross negligence or } \\
\text { wilful misconduct }\end{array}$ & $\begin{array}{l}\text { Ordinary contractual } \\
\text { liability }\end{array}$ \\
\hline Insurance & $\begin{array}{l}1981=\text { cl. } 311 \\
1990=\text { cl. } 311 \\
2007=\text { cl. } 3.11\end{array}$ & $\begin{array}{l}\text { Ordinary } \\
\text { contractual liability } \\
\text { Ordinary } \\
\text { negligence }\end{array}$ & $\begin{array}{l}\text { Gross negligence or } \\
\text { wilful misconduct }\end{array}$ & $\begin{array}{l}\begin{array}{l}\text { Ordinary contractual } \\
\text { liability }\end{array} \\
\text { Ordinary negligence }\end{array}$ \\
\hline
\end{tabular}




\begin{tabular}{|c|c|c|c|c|}
\hline DUTY & $\begin{array}{l}\text { RELATED } \\
\text { ClAuSE }\end{array}$ & $\begin{array}{l}\text { BREACH OF DUTY } \\
\text { UNDER THE } 1981 \\
\text { PROCEDURE }\end{array}$ & $\begin{array}{l}\text { BREACH OF } \\
\text { DUTY UNDER THE } \\
1990 \text { PROCEDURE (AS } \\
\text { INTERPRETED BY } \\
\text { ADECO) }\end{array}$ & $\begin{array}{l}\text { BREACH OF } \\
\text { DUTY UNDER THE } \\
2007 \text { PROCEDURE }\end{array}$ \\
\hline Taxes & $\begin{array}{l}1981=\text { cl. } 312 \\
1990=\text { cl. } 312 \\
2007=\text { cl. } 3 \cdot 12\end{array}$ & $\begin{array}{l}\text { Ordinary } \\
\text { contractual liability } \\
\text { Ordinary } \\
\text { negligence }\end{array}$ & $\begin{array}{l}\text { Gross negligence or } \\
\text { wilful misconduct }\end{array}$ & $\begin{array}{l}\text { Ordinary contractual } \\
\text { liability } \\
\text { Ordinary negligence }\end{array}$ \\
\hline $\begin{array}{l}\text { Application of } \\
\text { Accounting } \\
\text { Procedure }\end{array}$ & $\begin{array}{l}1981=\text { cl. } 501 \\
1990=\text { cl. } 501 \\
2007=\text { cl. } 5.01\end{array}$ & $\begin{array}{l}\text { Ordinary } \\
\text { contractual liability } \\
\text { Ordinary } \\
\text { negligence }\end{array}$ & $\begin{array}{l}\text { Gross negligence or } \\
\text { wilful misconduct }\end{array}$ & $\begin{array}{l}\text { Ordinary contractual } \\
\text { liability } \\
\text { Ordinary negligence }\end{array}$ \\
\hline $\begin{array}{l}\text { Operator to } \\
\text { Pay and } \\
\text { Recover from } \\
\text { Parties }\end{array}$ & $\begin{array}{l}1981=\text { cl. } 502 \\
1990=\text { cl. } 502 \\
2007=\text { cl. } 5.02\end{array}$ & $\begin{array}{l}\text { Ordinary } \\
\text { contractual liability } \\
\text { Ordinary } \\
\text { negligence }\end{array}$ & $\begin{array}{l}\text { Gross negligence or } \\
\text { wilful misconduct }\end{array}$ & $\begin{array}{l}\text { Ordinary contractual } \\
\text { liability } \\
\text { Ordinary negligence }\end{array}$ \\
\hline $\begin{array}{l}\text { Forecast of } \\
\text { Operations }\end{array}$ & $\begin{array}{l}1981=\text { cl. } 504 \\
1990=\text { cl. } 504 \\
2007=\text { cl. } 5.04\end{array}$ & $\begin{array}{l}\text { Ordinary } \\
\text { contractual liability } \\
\text { Ordinary } \\
\text { negligence }\end{array}$ & $\begin{array}{l}\text { Gross negligence or } \\
\text { wilful misconduct }\end{array}$ & $\begin{array}{l}\text { Ordinary contractual } \\
\text { liability } \\
\text { Ordinary negligence }\end{array}$ \\
\hline $\begin{array}{l}\text { Commingling } \\
\text { of Funds }\end{array}$ & $\begin{array}{l}1981=\text { cl. } 507 \\
1990=\text { cl. } 507 \\
2007=\text { cl. } 5.07\end{array}$ & $\begin{array}{l}\text { Ordinary } \\
\text { contractual liability } \\
\text { Ordinary } \\
\text { negligence } \\
\text { Fiduciary } \\
\text { obligation }\end{array}$ & $\begin{array}{l}\text { Gross negligence or } \\
\text { wilful misconduct } \\
\text { Fiduciary obligation }\end{array}$ & $\begin{array}{l}\text { Ordinary contractual } \\
\text { liability } \\
\text { Ordinary negligence } \\
\text { Fiduciary obligation }\end{array}$ \\
\hline $\begin{array}{l}\text { Distribution of } \\
\text { Proceeds to } \\
\text { Non-Taking } \\
\text { Parties }\end{array}$ & $\begin{array}{l}1981=\text { cl. } 605 \\
1990=\text { cl. } 606 \\
2007=\text { cl. } 6.06\end{array}$ & $\begin{array}{l}\text { Ordinary } \\
\text { contractual liability } \\
\text { Ordinary } \\
\text { negligence } \\
\text { Potential fiduciary } \\
\text { obligation }\end{array}$ & $\begin{array}{l}\text { Gross negligence or } \\
\text { wilful misconduct } \\
\text { Potential fiduciary } \\
\text { obligation }\end{array}$ & $\begin{array}{l}\text { Ordinary contractual } \\
\text { liability } \\
\text { Ordinary negligence } \\
\text { Fiduciary obligation }\end{array}$ \\
\hline $\begin{array}{l}\text { Operator's } \\
\text { Duties } \\
\text { Regarding } \\
\text { Conducting } \\
\text { Joint } \\
\text { Operations }\end{array}$ & $\begin{array}{l}1981=\text { art. } 7 \\
1990=\text { art. } 7 \\
2007=\text { art. } 7\end{array}$ & $\begin{array}{l}\text { Ordinary } \\
\text { contractual liability } \\
\text { Ordinary } \\
\text { negligence }\end{array}$ & $\begin{array}{l}\text { Gross negligence or } \\
\text { wilful misconduct }\end{array}$ & $\begin{array}{l}\text { Ordinary contractual } \\
\text { liability } \\
\text { Ordinary negligence }\end{array}$ \\
\hline
\end{tabular}




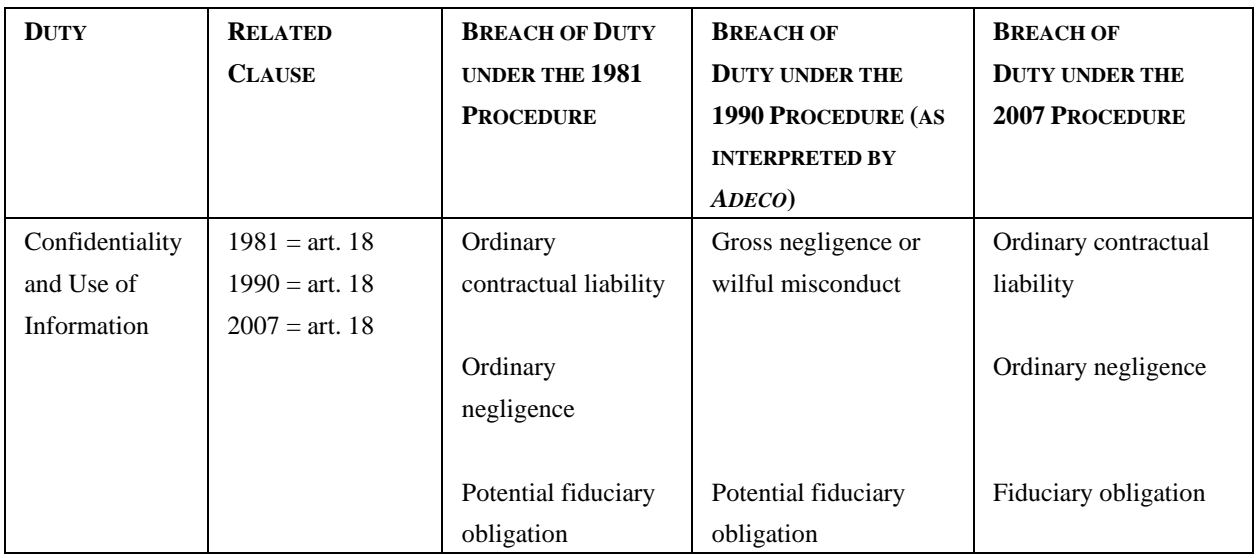

While operator liability under the 2007 Procedure has not yet been interpreted by the courts, based on the foregoing, it appears that the 2007 Procedure favours the operator less than the 1990 Procedure as interpreted in Adeco.

\section{B. FIDUCIARY DUTIES}

The evolution of the CAPL Procedure evidences a shift from the parties defining their relationship as one of strictly tenants in common, to the express undertaking by the operator (at least in certain defined circumstances) that it will act in the best interests of the nonoperators. This shift is likely a result of the jurisprudence, which suggests to arm's length commercial parties that if they intend for certain obligations to be fiduciary in nature, they should expressly state that in their operating agreement.

\section{THE AD HOC FIDUCIARY RELATIONSHIP}

\section{a. Lac Minerals Ltd. v. International Corona Resources Ltd..$^{59}$}

The test to determine whether an ad hoc fiduciary relationship exists was set out by the minority of the Supreme Court of Canada in Frame v. Smith ${ }^{60}$ and adopted by the majority of the Supreme Court in Lac Minerals. The test involves the following three-step analysis:

Relationships in which a fiduciary obligation have been imposed seem to possess three general characteristics:

(1) The fiduciary has scope for the exercise of some discretion or power.

(2) The fiduciary can unilaterally exercise that power or discretion so as to affect the beneficiary's legal or practical interests. 
(3) The beneficiary is peculiarly vulnerable to or at the mercy of the fiduciary holding the discretion or power. $^{61}$

Historically, the courts have placed significant emphasis on the third component: vulnerability. This is likely to be the case in considering the CAPL Procedures as well because the first two steps of the test can be satisfied by the functions and duties described in cl. 301 of the 1981 and 1990 Procedures, and cl. 3.01 of the 2007 Procedure. Each of these provisions delegate to the operator the management of the joint operations for the joint account. As a result, there is scope for the operator to both exercise some discretion or power, and to unilaterally exercise that power or discretion so as to affect the non-operators' interests (although the operator must still consult with the non-operators with respect to decisions being made and must inform the non-operators of operations planned or conducted).

\section{b. Galambos v. Perez}

The Supreme Court of Canada, in the recent case of Galambos, downplayed the significance of the vulnerability component, emphasized the fundamental importance of the existence of discretionary power to affect the legal or practical interests of the other, and added a fourth and critical requirement for an ad hoc fiduciary relationship to exist. This fourth requirement is the existence of an undertaking of loyalty. ${ }^{62}$

Ms. Perez, an employee/bookkeeper of a law firm founded by Mr. Galambos, contributed over $\$ 200,000$ of her own funds, of her own accord, to the firm's bank account in an attempt to keep the firm afloat. The firm was eventually placed into receivership. Galambos went bankrupt and Perez sued both the law firm and Galambos, claiming, inter alia, that she was owed a fiduciary duty in respect of the $\$ 200,000$ that she contributed. The trial judge disagreed and held that the relationship was one of debtor/creditor and was not fiduciary in nature. The British Columbia Court of Appeal disagreed with the trial judge and held that there was a fiduciary relationship because Perez was vulnerable and she had placed her trust in Galambos. Galambos took advantage of that trust and therefore breached an ad hoc fiduciary duty. The Supreme Court overturned the Court of Appeal's decision and upheld the trial judgment.

Justice Cromwell, delivering the unanimous decision for the Supreme Court, found that the "power-dependency" relationship, while important, is not sufficient on its own to impose a fiduciary relationship. ${ }^{63}$ There must be an express or implied undertaking provided by the fiduciary to act in the best interest of the other party. ${ }^{64}$ This undertaking of loyalty is a prerequisite for the existence of an ad hoc fiduciary relationship. Justice Cromwell explains as follows:

In my view, while a mutual understanding may not always be necessary (a point we need not decide here), it is fundamental to ad hoc fiduciary duties that there be an undertaking by the fiduciary, which may be either

Frame, ibid. at 136, cited in Lac Minerals, supra note 59 at 599.

Supra note 22 at para. 69.

Ibid. at para. 74 .

Ibid. at paras. 75-77. 
express or implied, that the fiduciary will act in the best interests of the other party. In other words, while it may not be necessary for the beneficiary in all cases to consent to this undertaking, it is clearly settled that the undertaking itself is fundamental to the existence of an ad hoc fiduciary relationship. ${ }^{65}$

Justice Cromwell also emphasized the importance of the second element of the Frame test; namely, that the fiduciary must have discretionary power to affect the legal and practical interests of the other party. He stated that

[i]t is fundamental to the existence of any fiduciary obligation that the fiduciary has a discretionary power to affect the other party's legal or practical interests. In Guerin, Dickson J. spoke of this discretionary power as "the hallmark of any fiduciary relationship" (p. 387) and, while making no comment on whether it was broad enough to embrace all fiduciary obligations, he endorsed Professor Weinrib's description of a fiduciary relationship as one in which "the principal's interests can be affected by, and are therefore dependent on, the manner in which the fiduciary uses the discretion which has been delegated to him” (p. 384). The influential guidelines set out by Wilson J. in Frame, at p. 136, for identifying new categories of fiduciary relationships included that the fiduciary have scope for the exercise of some discretion or power, the exercise of which affects the beneficiary's legal or practical interests. In Norberg, McLachlin J. noted that a fiduciary must be entrusted with such power in order to perform his or her functions (p. 275). ${ }^{66}$

The 2007 Procedure may provide more certainty for parties as it informs the courts of the express undertakings provided by the operator. Of course, the courts have the jurisdiction to impose an ad hoc fiduciary relationship where it finds that an implied undertaking was given. "Relevant to the enquiry of whether there is such an implied undertaking are considerations such as professional norms, industry or other common practices and whether the alleged fiduciary induced the other party into relying on the fiduciary’s loyalty." 67

Although Galambos does not deal specifically with parties in the oil and gas industry, the principles established by the Supreme Court must be applied in any case where the trial judge is asked to determine whether the particular facts of the case demand the imposition of an ad hoc fiduciary relationship. The language of the 2007 Procedure dealing with fiduciary duties will, undoubtedly, be relevant to this inquiry.

\section{THE FIDUCIARY OBLIGATION}

In Galambos, Cromwell J. found that "any breach of any duty by a fiduciary is not necessarily a breach of fiduciary duty." ${ }^{\text {" }}$ Thus, even where a court determines that the parties stand in an ad hoc fiduciary relationship, the court must also find that the particular duty is a fiduciary duty.

Ibid. at para. 83. See also Robert Flannigan, "Fact-Based Fiduciary Accountability in Canada” (2010) 36 Advocates' Q. 431, for a detailed analysis of the Galambos decision.

Galambos, ibid. at para. 79 .

Ibid. at para. 37, citing Rupert M. Jackson \& John L. Powell, Jackson \& Powell on Professional Liability, 6th ed. (London: Sweet \& Maxwell, 2007) at para. 2-130. 


\section{a. $\quad$ Luscar Ltd. v. Pembina Resources Ltd. ${ }^{69}$}

The Alberta Court of Appeal came to a similar conclusion in Luscar, the leading Alberta case dealing with operator fiduciary liability. In Luscar, the Court examined the existence and scope of fiduciary obligations between the operator (Pembina Resources Ltd.) and nonoperators (Norcen Energy Resource Ltd. and Luscar Ltd.) under a joint operating agreement. Justice Conrad for the majority held that although "there may be fiduciary aspects of the duties of an operator, not every duty is fiduciary."70 The operator may be put in a position of owing extended duties, "but it is important to examine carefully the alleged actions to ensure that they derive from the loyalty of the relationship, and are truly fiduciary obligations, as opposed to merely contractual, express or by implication."71

One of the issues in Luscar was whether the operator was under a fiduciary duty to provide notice pursuant to an area of mutual interest (AMI) clause in the operating agreement. The Court of Appeal held that the operator's failure to provide written notice pursuant to the AMI clause in an operating agreement did not create a fiduciary duty. Rather, the failure to give notice was a breach of contract.

The Court stated that all parties were sophisticated business entities with the capacity to prepare their own geological information and determine whether to acquire lands within the AMI. From the point when the operator developed its plan and formed an intention to purchase, it was obligated to forward that information to the others. However, "that obligation did not arise from a power or discretion the other two parties lacked." ${ }^{, 72}$ The Court found that the obligation was a contractual one, and "if it was breached, the parties could have sued for specific performance.”73 The Court went on to state as follows:

\footnotetext{
The failure here was simply a breach of a contract through an honest mistake or oversight in failing to give notice. That is not the type of unilateral exercise of power contemplated by Wilson, J., in Frame. She was talking about the exercise of a power that a fiduciary has because of its unique position or relationship. An honest mistake or oversight in failing to give notice was not an event that resulted from the exercise of a discretion arising from the strength of this relationship, nor were there facts to suggest the required type of vulnerability. Had the parties wished, they could have specifically provided that a failure to give notice extended the time or created a fiduciary duty. They did not do so. ${ }^{74}$
}

Where the contract does not suggest the duties at issue are fiduciary, the inclusion of a no partnership and entire agreement clause will "add weight to the argument that parties never intended fiduciary duties to be superimposed on the contractual ones."75 The fact that the parties had failed to provide for a fiduciary duty where they could have done so was "indicative of an intent to reduce all obligations to contractual ones."76 The Court stressed that the imposition of fiduciary duties into a commercial relationship was the exception rather

(1994), 162 A.R. 35 (C.A.) [Luscar], leave to appeal to S.C.C. refused, [1995] 3 S.C.R. vii.

Ibid. at para. 56 .

Ibid. at para. 58.

Ibid. at para. 72 .

Ibid.

Ibid. at para. 85 [emphasis added].

Ibid. at para. 91.

Ibid. at para. 77 . 
than the rule ${ }^{77}$ and cautioned that the imposition of fiduciary duties on an operator, in addition to the contractual duties, "would have a fundamental impact on the oil and gas industry.",78

\section{b. Erehwon Exploration Ltd. v. Northstar Energy Corp.}

In the earlier decision of Erehwon, Hunt J. held that each alleged fiduciary obligation must be interpreted in the contractual context to determine the nature and scope of the fiduciary duty. ${ }^{79}$ She went on to add that

[i]f a fiduciary duty would otherwise arise, and the contractual language specifically negatives this, in my opinion the fiduciary duty must give way to the contractual language the parties have chosen. To follow any other course would create an unwarranted degree of judicial interference in commercial relations. ${ }^{80}$

In most cases in which the courts impose a fiduciary duty, the fiduciary failed to discharge a legal duty for its own benefit. In Adeco, the Court of Appeal held that the operator must gain some advantage and that the conduct complained of by the non-operator must have been intentional before the court will impose a fiduciary duty on the operator. ${ }^{81}$ The Court cited with approval the British Court of Appeal decision of A.(C.) v. C.(J.W.): ${ }^{82}$

I conclude that it would be a principled approach to confine recovery based upon fiduciary duties to cases of the kind where, in addition to other usual requirements such as vulnerability and the exercise of a discretion, the defendant personally takes advantage of a relationship of trust or confidence for his or her direct or indirect personal advantage. This excludes from the reach of fiduciary duties many cases that can be resolved upon a tort or contract analysis, has the advantage of greater certainty, and also protects honest persons doing their best in difficult circumstances from the shame and stigma of disloyalty or dishonesty. ${ }^{83}$

The courts in Alberta have made it clear that when it comes to arm's length commercial parties, the court will look to the contract first to determine whether the obligation that has been breached can be remedied under the contract. Imposing a fiduciary duty will be a last resort and will only be available where the contract is silent on the issue, and where an undertaking of loyalty in respect of that obligation has been provided.

\section{c. Bank of Nova Scotia v. Société Générale (Canada)}

In Bank of Nova Scotia, ${ }^{84}$ the issue was whether the operator (Sorrel Resources Ltd.) was in a fiduciary relationship with the non-operators (a group of nine companies) such that the operator acted as a trustee for the non-operators with respect to undistributed revenues and prepaid expenses held by it for their benefit. The Court of Appeal held that the operator was in a fiduciary position and the non-operators were entitled to trace their funds even though

Ibid. at paras. 50-52.

Ibid. at para. 92.

Erehwon, supra note 26 at para. 142.

Ibid.

Supra note 14 at paras. 66-71.

(1998), 60 B.C.L.R. (3d) 92 (C.A.).

Ibid. at para. 85, cited in Adeco, supra note 14 at para 71.

Supra note 19. 
the operator was given the right to commingle those funds with its own under cl. 507 of the 1981 Procedure. The funds deposited were impressed with a trust on behalf of the nonoperators and the funds were not beneficially owned by the operator. Therefore, the operator's creditors had no claim over them, including Société Générale under its general assignment of book debts. ${ }^{85}$

\section{d. Brookfield Bridge Lending Fund Inc. v. Vanquish Oil \& Gas Corp. ${ }^{86}$}

The operator's breach of fiduciary duty in the context of commingling funds has recently been scrutinized by the Alberta Court of Appeal in Brookfield and does cause some concern for non-operators. This case suggests that even if the operator (as trustee) breaches its fiduciary duty to the non-operators, the court will be reluctant to impose a constructive trust where the operator is in receivership and there are other creditors involved and, in particular, where the trust funds cannot be traced to specific assets.

In Brookfield, the operator (Vanquish Oil \& Gas Corp.) of an oil well was required to remit 45 percent of the production revenue to the non-operator (Karl Oil and Gas Ltd. and Choice Resources Corp.). The operator never remitted the production revenues to the nonoperator and the amount outstanding was in excess of \$320,000. On 28 March 2007, the operator was placed into receivership by its secured lender, Brookfield Bridge Lending Fund Inc. (Brookfield). The property in question was subject to the 1990 Procedure. Clause 507 of the 1990 Procedure authorizes the operator to commingle its own funds with the funds it receives for the joint account. Clause 507 is as follows:

The Operator may commingle with its own funds the moneys which it receives from or for the account of the Joint-Operators pursuant to this Operating Procedure. Notwithstanding that moneys of a Joint-Operator have been commingled with the Operator's funds, the moneys of a Joint-Operator ... shall be deemed to be trust moneys, and shall be applied only to their intended use and shall in no way be deemed to be funds belonging to the Operator, other than in its capacity as the Joint-Operators' trustee. ${ }^{87}$

The operator maintained a general operating account and all transactions were processed through that account. As of 14 March 2007, the balance in the general operating account was $\$ 40,218$, representing proceeds from the well and the lowest amount that the account reached. On 16 March 2007, a final revenue payment from the well, in the amount of $\$ 40,598$, was deposited into the general operating account. As of the date of receivership the general account balance was in excess of $\$ 417,000$ and, of that, $\$ 58,000$ was attributable to the non-operator's share of production revenue.

The issue at trial ${ }^{88}$ was whether the express trust created by cl. 507 of the 1990 Procedure attached to the asset sale proceeds, effectively giving the non-operator a proprietary claim to those funds. Justice McDonald held that because the operator had breached the express trust set out in cl. 507 by failing to preserve the full amount of the production revenues in the 
general account, the operator had breached its fiduciary duties to the non-operator. ${ }^{89}$ In order to remedy the breach, McDonald J. applied the test from Soulos v. Korkontzilas, ${ }^{90}$ and imposed a constructive trust over all of the operator's assets (including the money realized in the sale of assets). ${ }^{91}$

The Court of Appeal reversed the trial decision and held that it was an error of principle to impose a constructive trust. The majority held that the non-operator is entitled to its proportionate share of the lowest balance in the general account (14 March 2007 — \$40,218) and the non-operator is entitled to its proportionate share of the additional trust funds $(\$ 40,598)$ deposited on 16 March 2007.92 The Court went on to state that the Soulos test was not satisfied as there was not sufficient evidence of what, if any, specific assets the operator purchased with the trust funds. It further stated that "[t]he ability to trace the trust funds into specific assets has always been central to the imposition of a constructive trust." ${ }^{\text {"3 }}$ Since the operator's wrongdoing could not be traced into any asset, that precluded the imposition of a constructive trust. $^{94}$

Furthermore, the majority found that the last branch of the Soulos test was not satisfied, namely that " $[\mathrm{t}]$ here must be no factors which would render imposition of a constructive trust unjust in all the circumstances of the case; e.g., the interests of intervening creditors must be protected."95 Justice Slatter stated as follows:

\begin{abstract}
It must be remembered that it is the respondents [non-operators] who created the risk of these circumstances arising by agreeing that trust and non-trust money could be commingled. Where the conduct of one party creates the problem, that is a relevant consideration in deciding whether a constructive trust should be imposed. $^{96}$
\end{abstract}

Justice Slatter went on to state that "[t]his appeal demonstrates the shortcomings of a practice, which is apparently an industry-wide practice, of letting oil well operators commingle trust funds with non-trust funds, while purporting to limit the ability of the

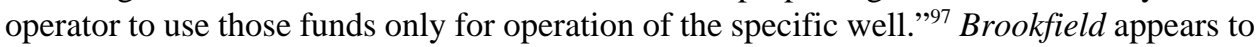
limit the remedies that a beneficiary (non-operator) would have otherwise had under Bank of Nova Scotia.

Ibid. at para. 38.

[1997] 2 S.C.R. 217 [Soulos].

Brookfield (Q.B.), supra note 88 at paras. 55-56.

The Court of Appeal applied the following principles in deciding this case: (1) "if the trust funds are commingled with non-trust funds, the trustee is generally presumed to have honest intentions, and to have spent the non-trust funds first" (Brookfield (C.A.), supra note 86 at para. 13, citing Re Hallet's Estate (1879), 13 Ch. D. 696(C.A.)); (2) "any remaining balance will be presumed to be trust funds. The claim of the beneficiaries is prima facie limited to the lowest intermediate balance in the account" (Brookfield (C.A.) at para. 13, citing Re Ontario Securities Commission and Greymac Credit Corp. (1986), 55 O.R. (2d) 673 at 677 (C.A.); (3) "further deposits to the account are not presumed to have the effect of replenishing the trust fund” (Brookfield (C.A.) at para. 15, citing Ontario (Real Estate \& Business Brokers Act, Director) v. NRS Mississauga Inc. (2003), 64 O.R. (3d) 97 at para. 49 (C.A.)); (4) "[a]bsent a clear intention by the trustee to replenish the trust ... further deposits are not attached by the express trust” (Brookfield (C.A.) at para. 16).

Brookfield (C.A.), ibid. at para. 19.

Ibid. at para. 20.

Soulos, supra note 90 at para. 45, cited in Brookfield (C.A.), ibid. at para.10.

Brookfield (C.A.), ibid. at para. 25.

Ibid. 
This case serves as a warning that even where the operator breaches its fiduciary duty, the court will be reluctant to impose a constructive trust where there are other creditors involved and, in particular, if the trust funds cannot be traced to the specific assets that the operator purchased with the trust funds. It is unlikely that creating separate trust accounts for each well and/or for each non-operator's proportionate share will be the realistic way forward. Non-operators will need to monitor the joint account and seek to remove the operator if required. As will be discussed below, if the operator is insolvent (or if any of the conditions under cls. 2.02A(a) to (d) of the 2007 Procedure are met), but the court refuses to allow an immediate removal of the operator, cl. 5.07 of the 2007 Procedure has been modified to terminate the operator's rights to commingle funds, in an effort to protect the funds of the non-operator in the joint account.

\section{THE DUTY OF GoOd FAITH}

In broad terms, the good faith standard requires the parties to have regard for each other's legitimate interests. This is a lesser standard than the fiduciary standard, which requires the fiduciary to act selflessly and with undivided loyalty to the other party, but is a higher standard than the unconscionability standard, which prohibits the parties from being excessively self-interested or exploitative. ${ }^{99}$ Thus, parties are not free to do exactly as they please in a good faith relationship; their conduct must meet the threshold standard governing the relationship in question. The good faith standard will take on a different meaning depending upon the facts in each particular case.

Looking to the language of the CAPL Procedure, particularly the definition of the relationship between the parties under cl. 1.05A of the 2007 Procedure, it appears that the intent of the drafting committee is to include a duty of good faith. The operator, therefore, needs to be cognizant of what it means to act in good faith and to be cognizant of what effect a particular decision can have on the non-operators.

\section{Gateway Realty LTD. V. ARton Holdings LTD. ${ }^{100}$}

The duty of good faith as a standard in contractual performance has been gaining momentum in Canada since the decision of Gateway. Gateway Realty Ltd. (Gateway) owned a shopping mall in which Zellers was the anchor tenant. Arton Holdings Ltd. (Arton) enticed Zellers to move into their new mall, which was in competition with Gateway's mall. Zellers assigned the remaining 17 years of its Gateway lease to Arton, who failed to approve new tenants for the mall despite the fact that Gateway brought several prospective tenants to Arton's attention. As a result, the former anchor store in the mall remained vacant, thereby jeopardizing the financial health of the entire mall. This prompted Gateway to commence an action against Arton for, inter alia, the breach of an implied duty of good faith to secure a suitable tenant.

At trial, the Court found that there was a breach that justified the termination of the assignment, stating: 
The law requires that parties to a contract exercise their rights under that agreement honestly, fairly and in good faith. This standard is breached when a party acts in a bad faith manner in the performance of its rights and obligations under the contract. "Good faith" conduct is the guide to the manner in which the parties should pursue their mutual contractual objectives. Such conduct is breached when a party acts in "bad faith" — a conduct that is contrary to community standards of honesty, reasonableness or fairness. ${ }^{101}$

A unanimous Nova Scotia Court of Appeal, in a short judgment, dismissed Arton's appeal without explicitly exploring all of the trial judge's views on the doctrine of good faith. The Gateway decision has been treated as a precedent for finding an implied duty of good faith and is often considered as a starting point for any judicial consideration of the doctrine of good faith.

\section{MESA OPERATING LTD. PARTNERSHIP V. AMOCO CANADA RESOURCES LTD. ${ }^{102}$}

Mesa, an Alberta trial decision of Shannon J., followed shortly on the heels of the decision in Gateway. Mesa confirmed that the doctrine of good faith limits the exercise of an operator's discretion in the oil and gas context.

In Mesa, the Court addressed the question of whether an operator has the unilateral power to pool royalty properties, and whether there was a limit on that power to pool granted in the contract. The operator (Amoco Canada Resources Ltd.) had drilled a successful gas well on one of the royalty properties and pooled that property with an adjacent half-section that Amoco owned outright, which had the effect of reducing the royalties that the non-operator (Mesa Operating Ltd. Partnership) would have received. The operator claimed that the contract granted discretion to pool properties, and that a duty to act in good faith required only that it could not act from bad motives. At trial, Shannon J. found in favour of the nonoperator and awarded judgment. The operator appealed.

The Alberta Court of Appeal upheld Shannon J.'s decision that a duty to act in good faith does not require that the plaintiff show that the defendant intentionally acted in bad faith, but rather, "the common law duty to perform in good faith is breached when a party acts in bad faith, that is, when a party acts in a manner that substantially nullifies the contractual objectives or causes significant harm to the other, contrary to the original purposes or expectations of the parties." 103 The Court of Appeal stopped short of holding that there exists an independent duty of good faith. It held as follows:

My only hesitation is whether one need, in this discussion, employ the term "good faith". In my view, we should hold carefully to the distinction between the two sources of rules about contracts, the law and the contract. Sometimes a rule of law imposes a duty or a constraint upon the parties to a contract despite their agreement, as is the case of the rules about illegal contracts and unconscionable contracts. On other occasions, however, the courts impose a rule upon the parties because we conclude that this fulfils the appeal to S.C.C. refused (1994), 162 A.R. 318 (note). For a more recent restatement of the principles in Mesa (C.A.), see Klewchuk v. Switzer, 2003 ABCA 187, 330 A.R. 40 at para. 33. Mesa (Q.B.), ibid. at para. 76, cited in Mesa (C.A.), ibid. at para. 14. 
agreement. In other words, the duty arises as a matter of interpretation of the agreement. The source of the rule is not the law but the parties. I worry that the term "good faith" in this case might blur that distinction. ${ }^{104}$

The Court of Appeal drew a distinction between imposing a duty in cases where it was outside the contract to do so, and cases where imposing a duty serves to fulfill the contract. In this case, imposing a duty to act in good faith was justified because the contract created certain expectations between the parties; since those expectations were reasonable, the Court saw fit to enforce them because "that is what the parties had in mind." 105 The Court arguably narrowed the application of the duty of good faith to those situations in which the parties, at the time of contracting, had a reasonable expectation about performance standards and procedures, stating as follows:

\begin{abstract}
In any event, it is not necessary for this case that I go further into this difficult area. This is because this case turns on a rule founded in the agreement of the parties, not in the law. In my view, as a matter of fact, this contract created certain expectations between the parties about its meaning, and about performance standards. If those expectations are reasonable, they should be enforced because that is what the parties had in mind. They are reasonable if they are shared. Of course, those expectations must also, to be reasonable, be consistent with the express terms agreed upon. This contract should be performed in accordance with the reasonable expectations created by it.
\end{abstract}

I therefore conclude that, at a minimum, the reasonable expectation of [the non-operator], at the time they made their agreement, was that [the operator] would consider both areal and reserves-based pooling, and follow whichever route the facts justified. That expectation might also have been that the operator would advise the holder of the gross royalty of all the facts of the matter in a case where the decision was anything but completely straightforward and, as here, there happened to be a conflict of interest.

The rule that governs here can, therefore, be expressed much more narrowly than to speak of good faith, although I suspect it is in reality the sort of thing some judges have in mind when they speak of good faith. As the trial judge said, a party cannot exercise a power granted in a contract in a way that "substantially nullifies the contractual objectives or causes a significant harm to the other contrary to the original purposes or expectations of the parties. 106

A narrow construction of the Court of Appeal's decision in Mesa is that the so-called duty of good faith is simply an extension of the parties' reasonable expectations that the specific contracted for provisions be performed as intended. ${ }^{107}$

Mesa (C.A.), ibid. at para. 15 [emphasis in original].

Ibid. at para. 19.

Ibid. at paras. 19, 21-22 [emphasis added].

For a narrow interpretation of Mesa (C.A.), see National Courier Services Ltd. v. RHK Hydraulic Cylinder Services Inc., 2005 ABQB 856, 390 A.R. 158, in which Topolniski J. states, "Mesa was not decided on good or bad faith principles as the court found the answer lay in the contract itself and the reasonable expectations it created about its meaning and performance standards, having regard to the commercial context" (at para. 31). Justice Topolniski goes ever further to add, "[i]n my view, the law in Alberta does not yet recognize a general duty of good faith in the performance of a contract" (at para. 32). 


\section{CANADA DEPOSIT INSURANCE CORP. V. CANADIAN COMMERCIAL BANK ${ }^{108}$}

A 1998 Alberta trial decision returned to the principles enunciated by the Mesa and Gateway cases. In Canada Deposit, a debt restructuring agreement resulted in Canadian Commercial Bank holding preferred shares in Western Securities Ltd. (Western), and entitled the bank to certain dividends and redemptions. Western refused to pay such dividends, and the Alberta Court of Queen's Bench held that Western's failure to comply with the terms of the agreement resulted not only in a breach of contract, but a breach of the duty of good faith to ensure that it made its best efforts in fulfilling the terms of the debt restructuring agreement.

In its decision, the Court relied upon the Gateway principle that parties have a duty to contract in good faith, and that duty limits the exercise of discretion by the contracting parties. ${ }^{109}$ The Court also returned to the Mesa principle that a party cannot exercise its power under a contract in such a way as to nullify the original purpose of the contract, or in a way that is contrary to the parties' original expectations. ${ }^{110}$

\section{CHASE MANHATTAN BANK OF CANADA V. SUNOMA ENERGY CORP. ${ }^{111}$}

With respect to the CAPL Procedure, the evolving doctrine of good faith was applied in relation to cl. 2401B, the right of first refusal clause (ROFR).

In Chase, the non-operator (Best Pacific Resources Ltd.) received a notice of ROFR issued by the receiver of the operator (Sunoma Energy Corp.), in connection with a sale of certain lands under a farmout agreement, which incorporated the 1974 Procedure. Clauses 2401B and 2402 of the 1974 Procedure ${ }^{112}$ describe the substance and procedure of the ROFR. The non-operator took the view that the consideration to be paid for the lands was grossly inflated and informed the receiver that it had a duty to act in good faith in defining a purchase price. The non-operator considered that the ROFR notice was invalid and failed to formally elect to, or not to, exercise the ROFR, though it did notify the receiver, through its solicitors, that it considered the ROFR notice to be invalid. At trial, the Court was asked to determine, among other issues, whether the receiver had failed to act in good faith in allocating a value to the ROFR-encumbered property.

Justice LoVecchio reiterated the principle from Gateway that there is "an implied duty of good faith in the performance of contractual obligations." 113 He cited with approval the 
Ontario Court of Justice (General Division) decision of GATX Corp. v. Hawker Siddeley Canada Inc.: ${ }^{114}$

It is well established that the grantor of a right of first refusal must act reasonably and in good faith in relation to that right, and must not act in a fashion designed to eviscerate the very right which has been given. $^{115}$

After concluding that an implied duty of good faith exists in relation to a ROFR, LoVecchio J. stated that it is the ROFR holder who has the evidentiary burden of proving that the other party has breached its duty of good faith in allocating value:

From the perspective of the ROFR holder, it will not suffice to simply argue that the allocated price does not in its view represent fair market value. While that may provide an indication that the allocation has been unfairly made or "loaded up," that alone will certainly not be conclusive. The ROFR holder will have to demonstrate on the evidence that the allocation principles applied by the purchaser and accepted by the vendor were unreasonable in the circumstances, or in other words that a duty of good faith has been breached. $^{116}$

Justice LoVecchio concluded that "[i]t is simply not enough for the ROFR holder to present a different valuation from that provided in the ROFR notice." ${ }^{\text {117 }}$ The non-operator needed to produce more evidence illustrating a breach of duty of good faith beyond merely showing that it would have assigned a different value to the lands. The evidentiary burden therefore was not met and the action was dismissed.

The Court of Appeal affirmed LoVecchio J.'s decision that the ROFR holder must do more than present a different valuation from that provided in the ROFR notice in order to satisfy the evidentiary burden that a breach of duty of good faith has occurred. Furthermore, showing that the vendor refused to reveal how it had arrived at the valuation of the lands was insufficient and did not establish a lack of good faith. ${ }^{118}$ Note, however, the caution in the Court's conclusion:

Under all the circumstances of this case, we cannot say that the Chambers judge wrongly concluded that [the non-operator] had failed to meet the burden of establishing Eravista's breach of good faith. This is not to say that, in a package sale situation, the ROFR holder must evaluate all the lands in the package in order to prove that the allocated price is not bona fides. Nor is it to say that the Chambers judge ought to have taken account of the possible impact of his decision in this case on rights relating to other lands in Parcel 6. But this error does not outweigh the other matters he properly took into consideration in reaching his decision. ${ }^{119}$

114 (1996), 27 B.L.R. (2d) 251 (Ont. Ct. J. (Gen. Div.)).

115 Ibid. at para. 72, cited in Chase (Q.B.), supra note 111, n. 5.

116 Clifford D. Johnson \& David J. Stanford, "Rights of First Refusal in Oil and Gas Transactions: A Progressive Analysis” (1999) 37 Alta. L. Rev. 316 at 335, cited in Chase (Q.B.), ibid. at para. 34. Chase (Q.B.), ibid. at para. 38.

Chase (C.A.), supra note 111 at para. 28.

Ibid. at para. 30. 


\section{REPLACEMENT OF THE OPERATOR: ALTERNATIVE NON-OPERATOR REMEDIES}

The standard of care that must be met by an operator under each version of the CAPL Procedure in order to obtain indemnification has been set out above. But what remedy is available to a non-operator if they are simply not satisfied with the current operator?

Article II in each version of the CAPL Procedure sets out the process for challenging and replacing an operator in a variety of circumstances. These circumstances were summarized by Professor Nigel Bankes as follows:

The CAPL operating procedure contemplates a number of ways in which the joint operator(s) can obtain a change in the operatorship: (1) for insolvency or similar reasons or purported assignment of the operatorship,

(2) by vote, or (3) by notice of default signed by a majority of parties (other than the operator) and where the default remain unrectified. $^{120}$

Each of the circumstances set out in art. II are important to maintaining the balance of power between the operator and the non-operators.

\section{A. THE OPERATOR BECOMES BANKRUPT OR INSOLVENT}

Under cl. 202(a)(i) of the 1981 and 1990 Procedures, and cl. 2.02A(a) of the 2007 Procedure, if the operator becomes bankrupt or insolvent the operator is to be replaced immediately upon notice from any non-operator. In the case of Norcen Energy Resources Ltd. v. Oakwood Petroleums Ltd., ${ }^{121}$ the Court found the operator (Oakwood Petroleums Ltd.) was insolvent but, pursuant to s. 11 of the Companies' Creditors Arrangement Act, ${ }^{122}$ the Court ordered a temporary stay until the operator had time to formulate a plan of compromise under the CCAA. This stay prevented the non-operator (Norcen Energy Resources Ltd.) from assuming operatorship under the 1981 Procedure.

As noted above, the drafting committee for the 2007 Procedure created a safeguard to protect the non-operators in the event that the court refused to allow the removal of an insolvent operator. Under cl. 5.07, if any of the conditions in cls. 2.02A(a)-(d) apply, and the non-operators are prevented from replacing the operator, the operator's right to commingle funds of the non-operators with its own funds is effectively terminated.

\section{B. BY VOTE}

The non-operators may, by vote, remove an operator against its will without providing grounds for such removal. This is useful where the operator's actions may be offside, but not to the degree of gross negligence or wilful misconduct (although the operator would still be indemnified for anything it did prior to being removed by vote). The efficacy of this

Nigel Bankes, “Challenge notices under the terms of the 1990 CAPL Operating Procedure”ABlawg (25 March 2010), online: The University of Calgary Faculty of Law Blog on Developments in Alberta Law <http://ablawg.ca/wp-content/uploads/2010/03/blog_nb_diazresources_abqb_march2010.pdf > . (1988), 92 A.R. 81 (Q.B.).

R.S.C. 1985, c. C-36 [CCAA]. 
provision is limited by both the proportion of the working interest, which needs a vote in favour (50 percent under the 1990 Procedure and 60 percent under the 2007 Procedure), and the fact that it is more common than not that the operator is the party that holds the largest working interest. Accordingly, in many cases the ability to remove an operator by vote may actually be a remedy without any practical value.

\section{BY DEFAULT OF THE OPERATOR WHICH REMAINS UNRECTIFIED}

If the operator defaults in its duties or obligations and does not rectify the default within 30 days of receiving notice, then the non-operators can remove the operator. Presumably, the removal of the operator can occur even if the non-operators cannot prove gross negligence or wilful misconduct - however, the non-operators will remain liable to indemnify the operator for any actions taken by the operator prior to such default. (This is assuming that the operator would otherwise be entitled to such indemnity under the operative CAPL Procedure).

\section{Challenging The OPERATOR}

Under cl. 203 of the 1981 and 1990 Procedures and cl. 2.03 of the 2007 Procedure, a nonoperator may give notice (the challenge notice) to the operator and other non-operators that it is prepared to conduct joint operations on more favourable terms and conditions. Clause 203 (and 2.03) requires that the challenge notice contain sufficient detail to enable the receiving party to evaluate the challenge notice and the effect it would have on the rest of the joint operators.

Clause 203 has been carefully construed by the courts so as to limit its applicability. In February 2010, the Alberta Court of Queen's Bench released its decision in Diaz Resources Ltd. v. Penn West Petroleum Ltd., ${ }^{123}$ denying the application made by the non-operator (Diaz Resources Ltd.), under r. 410(e) of the Alberta Rules of Court, ${ }^{124}$ for a declaration that it was entitled to replace the operator (Penn West Petroleum Ltd.). A challenge notice had been issued by the non-operator pursuant to $\mathrm{cl}$. 203 of the 1990 Procedure. Upon receipt of the challenge notice, the operator was required to either advise the joint operators that it was prepared to operate under the terms and conditions set out in the challenge notice, or elect to resign as operator within 90 days. Failure to elect one of those options results in a deemed election by the operator to resign.

The operator argued that the challenge notice was deficient and did not satisfy the requirement under $\mathrm{cl}$. 203 that the challenge notice, "contain sufficient detail to enable the receiving parties to evaluate the nature of the challenge notice and to measure the effect the revised terms and conditions would have on joint operations."125

Justice Kenny denied the application and provided some guidance as to the quality and type of information that a non-operator must provide to support a challenge notice. In the challenge notice, the non-operator offered to eliminate the costs associated with "field or 
production offices and first level supervisors in the field."126 However, the non-operator failed to indicate in the challenge notice what those costs would include and the impact their elimination would have on other costs. In finding the challenge notice contained insufficient information, Kenny J. stated as follows:

It is not sufficient in my view for [the non-operator] to say to [the operator] that they can figure out the impact themselves by reviewing the joint accounts. It is not up to [the operator] to try and figure out exactly what "costs" [the non-operator] intends to eliminate. ${ }^{127}$

Essentially, a non-operator who wishes to challenge the operator must be prepared to do their homework; this includes taking all reasonable efforts to calculate the potential costs and the impact those costs can have on the joint account. As the commentary to the 1990 Procedure notes, this may be an insurmountable task, as it is ultimately evaluated by the operator who is in a unique position to assess efficiencies. ${ }^{128}$ Furthermore, "a challenge on the basis of financial terms ... ignores the consideration that the basis of a challenge may be the operator's technical, rather than cost performance."129

Justice Kenny also discussed (but did not decide upon) the question of whether or not a challenging non-operator must also provide evidence in the challenge notice that it is capable of conducting operations as a competent operator in a good and workmanlike manner. She stated as follows:

I do not need to deal with this issue given my decision above. I would note however, that Penn West has raised issues with respect to the ability of Diaz to act as Operator. It is clear under Clause 203 of CAPL that the challenger must be ready, willing and able to conduct operations for the joint account on more favourable terms and conditions than the challenged party. It would appear to me that if there is any dispute with respect to that, it is not a matter which can be dealt with under an Originating Notice and the matter would need to proceed by way of Statement of Claim with the discovery and trial process. ${ }^{130}$

Under the 2007 Procedure, the words "ready, willing and able” were removed from cl. 2.03. It will be interesting to see how the courts interpret this clause and whether it will be held to be indicative of the parties' intent that the challenge notice need not include evidence that the proposed replacement operator will conduct operations in a good and workmanlike manner.

\section{FINAL THOUGHTS: OPERATOR/NON-OPERATORS AND THE EVOLVING CAPL PROCEDURE}

The authors hope that this article will assist the reader in more easily identifying the differences among the various CAPL Procedures, with a view to better understanding the likely balance of power between the operator and the non-operators in a given circumstances and which form of the CAPL Procedure best accomplishes the intended allocation of risk.

\footnotetext{
$126 \quad$ Diaz, ibid. at para. 13.

127 Ibid. at para. 14

128 CAPL, 1990 CAPL Operating Procedure (Annotated) (Calgary: CAPL, 1990) annotations to cl. 203.

129 Ibid.

130 Diaz, supra note 123 at para. 17 [emphasis added].
} 
We also hope that it will be useful for parties seeking to determine what, if any, remedies might most logically be pursued when issues arise under a given CAPL Procedure. Finally, we hope that the indication of the possible remedies available outside of the contract may assist the reader in considering these potential avenues of relief, where appropriate.

The CAPL drafting committees should be commended for their continued work on behalf of industry. The CAPL Procedure is but one of the various CAPL standard documents now widely used by industry and is one of the best examples of a living and evolving document. Its evolution, in response to changes in the industry or changes necessary because of the courts' interpretations of the document, speaks to the continued responsiveness of CAPL to industry needs. 